\title{
Formation of the Nationhood of the Mongolian-speaking Peoples of Innermost Asia
}

\author{
Pavel N. Dudin ${ }^{1}$ \\ Arkady V. Shemelin² \\ Andrey K. Pavlov ${ }^{1}$
}

${ }^{1}$ East-Siberian State University of Technology and Management, ${ }^{2}$ Transbaikal State University

E-mail: dudin2pavel@gmail.com

\section{Doi:10.5901/mjss.2015.v6n6s3p46}

\begin{abstract}
In the article authors describe the process of statehood within the borders of the historical-cultural space of Inner Asia in terms of its consistency and legitimacy, on the basis of the researches and developments of leading Russian and foreign scientists. There is an attempt to highlight the statehood models of the Mongolian peoples. The history of the unified Mongol state development, the process of decay and fate under the rule of the Qing Dynasty are traced. The authors draw attention to the contractual nature of the Manchu imperial power over Mongolia, and conditional voluntary transfer of power, that was used by the Outer Mongolia that proclaimed independence in 1911. Despite the fact that the sovereignty of Khalkha (Outer Mongolia) was not recognized by any state until 1945, it was able, with the support of first imperial and then Soviet Russia, to achieve the de facto independence of the head of the Buddhist Church - Bogd Gegen. He assumed the title of the Great Khan as the continuity of statehood of Genghis Khan. As an example of a failed attempt to achieve independence was the example of Inner Mongolia, which after the Xinhai Revolution tried to get the status of an independent state by repeating it in the years of 19331945. However, in both cases, the actions of the Mongolian aristocracy did not lead to the desired result, and during the Japanese occupation of Northeast China they provoked the dukes for the traitorous act and moved them to the side of the Japanese. It resulted in the creation of the Mongol-Go state or (later) Mengjiang that during the study period claimed the leadership of the Mongolian people in the world and was liquidated in August 1945, by the Soviet Union and Mongolian troops after Japan's defeat in World War II.
\end{abstract}

Keywords: Inner Asia, statehood, Mongol peoples, Outer Mongolia, Inner Mongolia.

\section{Introduction}

The history of the countries in the Asia-Pacific region does not contain many "white spots" any more. With the growing economic power of China, India and a number of other countries, scientists, specializing in various humanitarian areas, have explored the political and geographic space with enviable persistence. Even the People's republic of China, so distinctive for its history, culture, population and the role of the state in global geopolitics, leaves little room space for scientific discoveries and explorations.

The first half of the XX century appears to be decisive for the future of the countries in Innermost Asia. It was due to the fact that new state formations were emerging on the vast space, left after the collapse of large empires, changing the political structure of the region. In this regard, there are several groups of state formations of the Mongolian-speaking peoples, similar by several characteristics. We will call them models: (I) Khalkha as a political entity, progressively following from an autonomy to an independent state, as well as its "alternatives", which did not obtain the state sovereignty and failed to achieve international recognition. Within the post-Soviet territories, we can single out a few models of nationhood: (II) Soviet - the republican autonomy (Buryatia) and (III) Uryankhay - the Russian protectorate over the Uryankhay Krai, subsequently transformed into the Independent State of Tuva; the post-empire models of nationhood in Eastern Siberia: (IV) Dauria - Great Mongol State and (V) Khorin - the theocratic nationhood of Kodunai Erkhidzh Balgasan; the model of nationhood under the Japanese influence: (VI) Manchu Empire - Manchukuo , (VII) Mengjiang - the autonomous state of Mongolkuo in Inner Mongolia and (VIII) Ala Shang - the Western Mongolian Autonomy. 


\section{Literature Review}

Currently, this subject area is being developed by rather few Russian and foreign scientists. The recognized experts in this field are Caroline Humphrey (Humphrey, 1999), Christopher Atwood (Atwood, 2002), Uradyn Bulag (Bulag), and others.

However, Inner Asia as a subject of research in terms of statehood formation is primarily investigated by Russian scientists. The development of independence of Mongolian lands in the first half of the $20^{\text {th }}$ century is addressed by P.N. Dudin and K.B.-M. Mitupov (Dudin \& Mitupov, 2012). In their works they write about the international legal status of Mongolia after it proclaimed independence in 1911, describe the geopolitical environment in Inner Asia in the early $20^{\text {th }}$ century, and make a projection onto the modern political map of the Eurasian continent.

The process of state building in the soviet period is covered by E.N. Palkhaeva (Palkhaeva, 2014) and A.A. Yelaev (Yelaev, 2014). Their works are distinguished by withdrawing from the traditional soviet understanding of state and polity building processes where they rather boldly claim a national factor as a driving force in independence issues at a certain historical stage. A recognized expert on Tuva statehood is V.A. Vasilenco (Vasilenco, 2014) and V.G. Datsyshen (Datsyshen, 2003) - the author of a number of books and numerous articles on the history of Uryankhaisky Krai and the Russian-Chinese relations in its respect. "The Great Mongolian State" and the circle of its founders, including the ataman Semenov and the "government leader" Naise Khagan, are studied in detail by L.V. Kuras (Kuras, 2015), and the attempt to proclaim independence and to create an independent theocratic state in the territory of two municipal districts of the present Buryatia is researched by N.V. Tsyrempilov (Tsyrempilov, 2015).

Creation and development of the state and social system of Manchukuo are addressed by M.V. Krotova (Krotova, 2014) - a recognized expert on Russian emigration. The only researcher for the statehood of Inner Mongolia today is P.N. Dudin, whose scientific works are for the most part dedicated to Mengjiang (Dudin, 2014) and the so-called Alashan Republic or the West-Mongolian Autonomy (Dudin, 2014).

We should separately mention the phenomenon of nationhood of the Far Eastern Republic (Shemelin, 2015) and Tibet (Kuzmin, 2010), which, though not acting as "uniting powers" of the Mongolian people, had their own positions in the general trend of the nationhood process.

\section{Research Methodology}

In methodological terms, the presented research is done in the form of post-nomadic research. The theoretical message of such research is based on the works of G. Deleuze and F. Guattari and their speculations about the essence of nomadology in the present post-modern discourse. To this end, the works by J. Scott should also be mentioned as they contain considerations regarding nomad sedentarization, formation of boundaries and high art nouveau. «The End of Nomadism?» - a book by D. Sneath and C. Humphrey that has already become classics - also relates here. The book describes the social and cultural changes experienced by nomad Mongolian speaking nations of Inner Asia. In general, the methodological procedure for comprehending the problem in question is mainly built around the post-modern understanding of the role that the state plays in the modern society.

\section{Findings and Discussion}

The history of the Mongolian statehood is rooted in the beginning of the XIII century, when a representative of the clan of Bordzhigin was elected the Great Mongol Khan at the quriltai in 1206. The subsequent history is linked to aggressive wars and the formation of the largest state in the history of mankind. Therefore, this period can be seen as a "starting point" in a long and difficult road of the formation of the Mongolian nationhood, which was undulating in nature, resulting in periods of prosperity, unity and power, followed by periods of decline and disintegration.

The period of disintegration of the state, created by Genghis Khan, is associated with the death of the Great Khan Mungke in 1259. Kublai Khan, who refused to follow Genghis Khan's Great Yasa, was not recognized as a legitimate ruler. As a result, the state entered a period of the so-called "first collapse": once a powerful empire breaks into the states of Ilkhanate and Golden Horde, which later turned into independent political formations. Thus, the sovereignty of the Great Mongolian State began to "dissolve" among its successor states, which were also losing it as a result of collapses or conquests.

In the XIV-XV centuries, Mongolia lived through further development of the feudal hierarchy and, respectively, "the second collapse". However, at the turn of the XV-XVI centuries, one of the most important rulers-descendants of the great conqueror Dayan Khan (1479-1543) succeeded to unite the country once again, for a short period. It disintegrated into 
pieces after his death, permanently. From the same period, the history of the Mongolian peoples began to cover not Eastern and Western Mongolia, but also the division of Eastern Mongolia into Northern and Southern parts. The Gobi Desert became a natural southern boundary. Descendants of Dayan Khan's eldest line occupied the land in Southern Mongolia, descendants of his younger son Geresendze founded multiple clans of powerful princes in the North of the country - in Khalkha.

However, in the same period, a force was being formed in the East. It managed to conquest not only disparate Mongol principalities but the Ming Empire - the Manchu state formation, eventually extending its influence to China, Mongolia, Korea and a number of other, smaller Asian states. Representatives of Inner Mongolia and the Chakhar Khanate, the largest and strongest state located in present-day northern China, demonstrated the greatest resistance to the Manchu rulers. The supreme ruler of the Khanate was defeated, his descendants were unable to show any meaningful resistance, resulting in convening of the congress of 49 southern and eastern Mongolian princes in Chifeng two years later, in 1636, at the behest of the Manchu khans. The congress made the fateful decision to assign Abakhai as the Great Khan with the title of the Chinese Emperor (Bogdo Khan). As a result, the remains of the state sovereignty were permanently lost, the rights of princes from Southern and Eastern Mongolia were transferred to the Manchu. State entities, occupying those lands, lost their state sovereignty. Inner Mongolia first appeared on the political map of the time, formed on the south-eastern lands of the Mongols.

Khalkha, or Northern Mongolia, was then called Outer Mongolia and maintained its independence. The most active and popular North-Mongol princes, starting from 1640, attempted from time to time to establish a political or at least military unification in the face of the loss of independence. Then, on the initiative of the Oirat rulers, they convened a congress, which was attended by 44 princes and the Church hierarchies. The main goal was to establish peace between princes and fight the Manchu threat together. However, that alliance, as well as the made peace, proved to be short-lived. Rivalries, disputes and conflicts, deliberately instigated by the Manchu, led to a new outbreak of fighting between feudal lords. As a result, the Mongols failed to reach their goal of forming an effective block of principalities, capable to reflect the Manchu onslaught.

Then, there was a series of internecine wars, actively supported and fueled by the Manchu. In 1688, the Oirat Khan Galdan defated the joint Khalkha troops of local feudal lords, making them seek protection from the Qing dynasty. Princes and the first hierarch of the Mongolian Church fled into the territory of Inner Mongolia, where they adopted the Manchu citizenship.

The next stage of the nationhood formation and conversion of the Mongolian nationhood is associated with the events of the Dolon Nor Congress of the Khalkhi khans, during which the rights of those princes were legally and legitimately assigned to the Qing dynasty, with Outer Mongolia incorporated into the Chinese power. In mid-June 1696, Galdan Khan was defeated by the Qing troops near Toradji. Thus, Khalkha lost its state sovereignty and became the territory of the Qing Empire (Bezprozvannykh, 2005).

After the death of Galdan Khan's grandnephew Galdan-Tseren in 1745, the feudal dissension continued. Chinese authorities took advantage of this. In 1755, 1756 and 1757, they sent their army to Jungaria, finally destroying the Khanate. The process of eliminating sovereign Mongolian principalities, which lasted from 1634 to 1758, was completed.

$\mathrm{K}$. Demeberel in his work «Influence of the international environment on development of Mongolia: a comparative analysis in the historical context of the XX century" writes, "One of explorers of Mongolia, Colonel Baranov, according to the newspaper Baikal News, managed to find a very important act in ancient Mongolian archives. The document relates to the XVII century, telling about the Mongols electing the Manchu Emperor as their Khan. The act was a response from the Chinese emperor and defined the rights of Mongolian princes as sovereigns of their principalities. In conclusion, the document stated that, in case of a fall of the dynasty, all initial laws would be restored". Thus, the rights of the Mongols to sovereignty were passed to the Chinese emperor as a result of a contractual nature.

After the total loss of any state autonomy and becoming a colony of neighboring states in the XVIII century, various branches of the Mongols were divided. However, the process of recovering nationhood took place in the XX century on the territories of nomad camps.

In the early XX century, the Mongolian ethnic group was in the citizenship of several states at once. The Buryat and Kalmyk peoples were part of the Russian Empire, their status and legal situation were regulated in different ways. Another part of the Mongolian peoples was in the Chinese citizenship, as well as in Russia, their status and situation varied. Those Mongols, who lived to the South of the Gobi Desert, occupied the territory, later named Inner Mongolia, it was part of China's territory and now is an administrative-territorial unit with a special status.

In 1911, Outer Mongolia (Khalkha), after expelling the Manchu Governors, declared its independence. The Temporary Plenipotentiary Administration (Government) of the Khalkha Khure (Халхын Хvрээний бvх хэргийг тvр ерєнхийлєн шийтгэх газар), established on November 30, 1911, released a universal proclamation on the independence 
of all Mongolian peoples. On December 1, 1911, 4 aimaks in Outer Mongolia circulated a proclamation, which declared the establishment of the independent Mongolian state.

The reason to resume fighting for national independence was related to the events, taking place in China at the turn of the 1911-1912. On January 1, 1912, the Temporary Government of the Republic of China gained political power over the country and passed to the formation of the republican institutions, while maintaining the monarchy nominally. The political center of the revolutionaries was located in Nanjing, led by the Acting President Sun Yat-Sen. In fact, the renewed nationhood inherited both the territory and tradition of the previous Qing Empire, turning into a multi-ethnic republic, which comprised, besides the Khanate lands, the territory of Tibet, Outer and Inner Mongolia. 5 principles of Sun Yat-Sen, the essence of which was to share harmonious living "under a common roof", served as a basis for that multicultural civilization. However, those principles were ideal and did not take into account centrifugal tendencies, gaining force on the outskirts of the Chinese lands.

With the fall of the Qing dynasty and the establishment of the Chinese Republic in 1911, the revolutionary spirit penetrated the consciousness of the Mongols, who did not fail to take advantage of the prevailing confusion and declared their independence. At the same time, there wad an increased activity on the part of the Russian Empire in the region, which was connected with its very significant geopolitical interests in Mongolia and China. Similar activity was demonstrated by Japan, the interests of which also laid in that geographical area. The reasons, for which the two powers intervened in the processes of recovering of the Mongolian nationhood, were based on the fact that, after the RussianJapanese agreement of 1907, Mongolia ceased being just an object of the Russian-Chinese relations. It became an equally important object in the Russian-Japanese relations (Demberel, 2002). An agreement was reached, which consisted of a transparent convention, stating the commitment of both powers to the principle of maintaining the status quo in Far East, as well as a secret treaty, ensuring the inclusion of Northern Manchuria and Outer Mongolia into Russia's sphere of influence, with Southern Manchuria and Korea - in Japan's sphere of influence. In general, the Mongolian question de jure was governed by those agreements, at least until the end of the cold war. Inner Mongolia (Art. 2) was divided via the Beijing Meridian into the Eastern (Japanese) and Western (Russian) spheres of influence (Collection..., 1906).

Negotiating with Russia, Japan expanded boundaries of its sphere of influence in the region, resulting in the "division" of the Mongol peoples, already depending in various degrees on the Qing China, into different areas of geopolitical interests. Thus, the northern lands of the Mongol peoples - Khalkha or Outer Mongolia - were included in Russia's sphere of influence, staying there until the collapse of the Soviet Union. The southern and eastern lands fell within the scope of Japan's influence that led to the formation of several state-like entities in Northern and Central China in the 1930s: Mongolkuo, Chanang, Jinbei. With the help of the Kwantung army, Japan began to use the controlled territories to their advantage (Dudin, 2015). Proclaiming independence at first, they were merged into the State of Mengjiang in 1939.

After the establishment of the pro-Japan government in March 1940, led by Wang Jingwei, Mengjiang was included into its nominal jurisdiction, retaining actual independence. In accordance with the agreements, concluded in August 1943 between the authorities of Japan and the Government of Wang Jingwei, Japan received the right to deploy its troops within the Mongolian Autonomous Federation, the political role of which gradually decline since November 1943.

\section{Concluding Remarks}

Following the defeat of Japan in August 1945, most regimes, established with the support of the Kwantung army, ceased to exist. The same fate befell Mengjiang, although there was another attempt to form an autonomous political power within the boundaries of the western part of Inner Mongolia 4 years later. After the end of the World War II, its former President, Prince De Wang was arrested. For four years, he lived in Beijing under the supervision of the Kuomintang. In August 1949, just before the Communist Party, led by Mao Zedong, extended its political influence over the entire China, the Kuomintang authorities were forced to leave the country and flee to Taiwan, Dae Wang proclaimed the creation of the Autonomous Government in Ala Shang - the Republic of Ala Shang. In November-December of the same year, the Chinese army occupied all strategic points of the republic, Dae Van ran to Mongolia, where later he was arrested and delivered to Chinese authorities.

The history of the formation of statehood and a relative independence of Inner Mongolia ended, as well as a short but important stage of reviving the ideas about their own nationhood among the Mongolian peoples, dreaming of autonomy since the Chifeng Congress of 1638 , but being unable to fully implement, develop and maintain.

Other territories of the Mongolian speaking nations were either merged in the Soviet Russia or came under its 
influence: Buryatia was divided between the RSFSR and the Far Eastern Republic that later on became part of the RSFSR. Tuva preserved its status as an independent state up to 1944, after which it was also included into the RSFSR. Only Mongolia that in 1924 was proclaimed the Mongolian People's Republic has gained independence and has become, and is so far, a full-fledged participant of international relations.

\section{References}

Atwood, Ch. (2002). Young Mongols and Vigilantes in Inner Mongolia's Interregnum Decades, 1911-1931. Brill Academic Pub. Bezprozvannykh, Ye.L. (2005). Tibetan-Chinese relations in the XVII-XVIII centuries. Volgograd, Volga State University Pub.

Bulag, U.E. (2013). The 13th Dalai Lama in Mongolia, or the Dawn of Inner Asian Modernity, Introduction to The Thirteenth Dalai Lama on the Run (1904 - 1906): Archival Documents from Mongolia. Leiden: Brill Pub.

Collection of the most important treatises and conventions, concluded between Russia and foreign powers, Warsaw, 1906.

Datsyshen, V.G. (2003). Sayan Knot: Usinsko-Uryankhaisky Krai and Russia-Tuva Relations in 1911-1921.- Kyzyl Pub.

Demberel, K. (2002). Influence of the international environment on development of Mongolia: a comparative analysis in the historical context of the $X X$ century. Irkutsk: Ottisk Pub.

Dudin, P.N. (2014). Mongolian Alashan Republic as a political project of the 1940. East. Afro-Asian societies: history and modernity. No. 2, 33-42.

Dudin, P.N. (2014). Political history of Mengjiang. Ulan-Ude: Buryat State University Pub.

Dudin, P.N. (2015). The Policy of Japan Concerning Natural Resources of Mengjiang: Legal Aspects. Mediterranean Journal of Social Sciences. MCSER Publishing, Rome-Italy. Vol 6. No 3. May, Doi:10.5901/mjss.2015.v6n3p, 131-137.

Dudin, P.N. \& Mitupov, K.B.-M. (2012). Formation of the Mongolian nationhood (first half of the XX century). Ulan-Ude: Buryat State University Pub.

Humphrey, C. (1999). Society, the State and the Environment in Inner Asia. By Caroline Humphrey and David Sneath, Duke University Press / White Horse Press, Durham USA and Cambridge UK Pub.

Krotova, M.V. (2014). Peculiarities of creation and functioning of the State of Manchukuo (1932-1945). In K.B.-M. Mitupov (Ed.), Nationhood of peoples of Innermost Asia (XX century) (162-190). Prague: Vědecko vydavatelské centrum «Sociosféra-CZ» Pub.

Kuras, L.V. (2015). Great Mongol State of Ataman Semyonov: The State, which never. Eurasia: statum et legem, No. 1 (4), 84-97.

Kuzmin, L.S. (2010). Hidden Tibet: history of independence and occupation. St. Petersburg: Andrei Terentyev Pub.

Palkhaeva, Ye.N. (2014). Creation of Buryat-Mongolian autonomous communities within the Far-Eastern Republic and the RSFSR as the initial stage of self-determination of the Buryat people (1917-1922). In K.B.-M. Mitupov (Ed.), Nationhood of peoples of Innermost Asia (XX century) (41-99). Prague: Vědecko vydavatelské centrum «Sociosféra-CZ» Pub.

Shemelin, A.V. (2015). Formation of nationhood in the context of the Far Eastern Republic. Eurasia: statum et legem, No. 1 (4), 108-132.

Tsyrempilov, N.V. (2015). Constitutional Buddhist theocracy of Lubsan-Samdan Tsydenov (1918-1922): basic law and the structure of the state. Eurasia: statum et legem, №. 1 (4), 61-71. 